\title{
Future ecological studies of Brazilian headwater streams under global-changes
}

Estudos ecológicos futuros em riachos de cabeceira na perspectiva de mudanças globais

Marcos Callisto ${ }^{1}$, Adriano Sanches Melo²,

Darcilio Fernandes Baptista ${ }^{3}$, José Francisco Gonçalves Junior ${ }^{4}$,

Manuel Augusto Simóes Graça ${ }^{5}$ and Fernanda Gaudio Augusto ${ }^{6}$

${ }^{1}$ Laboratório de Ecologia de Bentos, Departamento de Biologia Geral, Instituto de Ciências Biológicas, Universidade Federal de Minas Gerais - UFMG, CP 486, CEP 30161-970, Belo Horizonte, MG, Brazil e-mail: callistom@ufmg.br

${ }^{2}$ Departamento de Ecologia, Instituto de Ciências Biológicas, Universidade Federal de Goiás - UFG,

CP 131, CEP 74001-970, Goiânia, GO, Brazil

e-mail: asm.adrimelo@gmail.com

${ }^{3}$ Laboratório de Avaliação e Promoção da Saúde Ambiental - LAPSA, Instituto Oswaldo Cruz - IOC, Fundação Oswaldo Cruz - Fiocruz, Av. Brasil, 4365, Manguinhos,

CEP 21045-900, Rio de Janeiro, RJ, Brazil

e-mail: darcilio@ioc.fiocruz.br

${ }^{4}$ Laboratório de Limnologia, Departamento de Ecologia, Universidade de Brasília - UnB,

CEP 70910-900, Brasília, DF, Brazil

e-mail: jfunior@unb.br

${ }^{5}$ Departamento das Ciências da Vida, Instituto do Mar, Centro do Mar e do Ambiente,

Universidade de Coimbra, Coimbra, Portugal

e-mail:mgraca@ci.uc.pt

${ }^{6}$ Laboratório de Ecologia Isotópica, Centro de Energia Nuclear na Agricultura,

Universidade de São Paulo - USP, Av. Centenário, 303, CEP 13416-000, Piracicaba, SP, Brazil

e-mail: fer_gaudio@yahoo.com.br

\begin{abstract}
This paper results from discussions triggered during the "Stream Ecology Symposium" that took place at the XIII Congress of the Brazilian Society of Limnology in September of 2011 in Natal, Brazil. Based on our experiences, we have raised several questions regarding ecological studies of headwater streams facing threats under globalchanges and proposed numerous subjects to be addressed in future studies in Brazil. These studies deal with the necessity of knowing species biology and the elaboration of models to assess changes (which implies the availability of time-series or large-scale data sets); the ecology of riparian zones and the interchange of materials and energy across the land-water boundaries; forest conversions and standardized sampling strategies and data treatment to assess global change.
\end{abstract}

Keywords: global change, stream ecology, riparian zones, long-term monitoring, macroinvertebrates.

Resumo: Este artigo resulta de discussóes ocorridas durante o Simpósio de Ecologia de Riachos que aconteceu durante o XIII Congresso da Sociedade Brasileira de Limnologia em setembro de 2011 em Natal, Brasil. Baseados em nossa experiência, propomos algumas perguntas sobre ecologia de riachos na perspectiva de mudanças globais e sugerimos alguns aspectos a serem abordados em futuros estudos no país. Esses estudos estáo relacionados à necessidade de se conhecer a biologia das espécies; à elaboração de modelos para avaliar as mudanças (o que implica a necessidade de um grande volume de dados em larga escala temporal e espacial); a ecologia das zonas ribeirinhas e o intercâmbio de materiais e energia através das interfaces terra-água; as alteraçóes na cobertura florestal e estratégias de amostragem e tratamento de dados padronizados para avaliar as mudanças globais.

Palavras-chave: mudanças globais, ecologia de riachos, zonas ripárias, estudos de longo prazo, macroinvertebrados. 


\section{Introduction}

Despite their small size, headwater streams comprise nearly $80 \%$ of all aquatic routes in a basin (Benda et al., 2005). They have a prominent role in the ecology of flowing waters, particularly regarding the dynamics and transport of organic matter (energy and nutrients), and their importance can be extended if trophic linkages between terrestrial and aquatic zones are included. Finally, these systems sustain a diverse and unique fauna (Gessner et al., 2010) and are excellent ecological corridors for species dispersal through watersheds (Méio et al., 2003).

Headwater streams also provide ecological services to human beings, including high-quality water for human use and conversion of organic matter into biomass capable of sustaining fish, birds and many other consumers (Costanza et al., 1997; Dudgeon et al., 2006). However, their close relation with terrestrial systems makes small streams vulnerable to land conversion and other related perturbations (Vörösmarty et al., 2010; Woodward et al., 2012). Certain impacts may promote changes at the planetary scale, including global warming, increased river nutrient load and deforestation. Given that rivers, particularly headwater streams, are among the most diverse systems on the planet and are the most threatened (Dudgeon et al., 2006), there is a need to understand how these systems may change under a global changing scenario.

This paper results from the Stream Ecology Symposium which took place at the XIII Congress of the Brazilian Society of Limnology in September 2011 in Natal, Brazil. At this congress, the authors discussed how headwater Brazilian streams have been altered under global changing scenarios, giving particular emphasis to macroinvertebrates and riparian plants. After the Natal meeting, the authors engaged in follow-up discussions regarding the main topics through e-mail, particularly concerning the implications of global changes on the subject presented at the symposium. Here we define global changes as any man-made changes on natural aquatic systems from any scale capable of altering natural ecological processes of headwater streams and rivers. Such changes include, for instance, global warming, eutrophication of inland waters, changes in phosphorous cycles, and large-scale deforestation and/or forest conversion. We do not intend to review how all these threats affect stream ecosystems, rather this paper outlines some important questions that could be addressed by Brazilian researchers in a near future in order to better understand how largescale human alterations have modified headwater streams in a species-rich continent.

\subsection{How can we predict the structure of benthic macroinvertebrate communities under global environmental change?}

Stream environments are a combination of particular meso- and microhabitats sequences (Frissell et al., 1986) and forms hierarchical system composed by multiple spatial scales (Cooper et al., 1998). A considerable amount of research effort has been invested to understand how spatial scales influence structural and functional organization of streams and how environmental factors can affect their biological communities.

Many studies have aimed at understanding the longitudinal gradient of communities, including species distributions, functional feeding group composition, and predictable changes of communities from headwaters to large rivers downstream. Others have evaluated the patterns of distribution of macroinvertebrates, community organization and assessed biological traits of species at many different scales (Statzner et al., 2007; Munn et al., 2009). Consequently, a considerable amount of data has been accumulated on overall patterns of stream macroinvertebrate assemblage structure, but few multifactorial studies have assessed community spatial patterns, particularly the relationship between regional-local richness and latitudinal diversity patterns of stream macroinvertebrates in both basic and applied sense (Purvis and Hector, 2000; Heino et al., 2005).

The natural geographic structure of assemblages generates important information for basic ecological studies and environmental management. These geographic models are used to predict the community composition of fauna and flora from environmental data not likely to be affected by human actions (e.g., altitude, geology) and would indicate what basic structure should be maintained when evaluating anthropogenic effects on biological communities. Although current climate is a powerful factor predicting species distribution, community structure and functional organization of aquatic macroinvertebrates, few studies in Brazil have addressed this subject.

Important human threats influencing the structure of macroinvertebrate communities identified with predictive models include nonpoint pollution, deforestation, and land conversion for agricultural activities at local and watershed 
scales (Feio and Poquet, 2011). Recently, special attention has been given to the identification of reference stream sites (Reynoldson et al., 1997; Feio and Poquet, 2011), mainly for the application of biological monitoring programs.

Long-term biological monitoring under the Reference Condition Approach (hereafter RCA; Feio and Poquet, 2011) can inform about biological changes caused by global nutrient increases and forest changes if the reference sites are maintained for comparisons. However, under global warming scenario, the condition of reference sites is also expected to change through time and the challenge in this case is to identify strategies to cope with permanently changing thermal situation. Therefore, although many reference sites are needed for local biological monitoring, they may no longer be a good benchmark for monitoring global-scale threats (e.g., global rising temperature). Conversely, if sufficient data were collected (in terms of number of sites and temporal repetition), the present distributions of organisms and their changes over time could be used as reference to evaluate the effects of global warming on stream ecosystems. Many stream taxa are notably sensitive to small changes in water temperature, and thus we could expect severe reductions and changes in species range distribution. Indeed, this method has been applied for terrestrial and aquatic organisms (e.g., Thuiller et al., 2005; DinizFilho et al., 2009; Tisseuil et al., 2012).

According to Isaak et al. (2011), the following four key points should be considered when evaluating the effects of climate changes on aquatic insects: i) Stream temperature is a critical determinant of aquatic species growth, survival, distribution and reproduction; ii) Empirical evidence suggests that streams are warming in response to global warming; iii) Models at regionalscale are needed to consistently and accurately predict the oscillation of water temperature and aquatic organisms on streams. The development of these models is possible using existing temperature data in conjunction with spatial analysis techniques (e.g., MDS), which relates the temperature with altitude; iv) Long-term stream water temperature monitoring which will allow applications for understanding climate effects.

Another possible approach is to use traits to determine sensitivities and tolerances of individual species to track changes in water conditions in a global change scenario. This approach could be undertaken to support management planning by identifying taxa that are most at risk when water quality changes. The traits of species have been considered an alternative to the taxonomic composition on studies assessing human effects on water bodies and macroinvertebrates assemblages (Brooks et al., 2011).

\subsection{Other models in the global warming scenario}

Climate change scenarios predict rapid changes in many environmental variables, including temperature, and frequency and magnitude of floods and droughts. Global climate change potentially affects biota at all scales because many taxa have restricted limits of tolerance. Moreover, non-lethal effects can be expected through decreased fitness due to the reduction of the biota's real niche. Climate change can also threaten species through habitat reduction and range shifts.

What climatic variables can be used to predict changes in the macroinvertebrate community structure in streams? Variables affecting the biology of species in certain phases of their life cycles must be selected. Such variables may include the annual number of dry days, the total precipitation, the number of consecutive days with $\mathrm{X} \mathrm{mm}$ of precipitation, the minimum, average and maximum temperatures, the relative air humidity, and total insolation. For tracking biological responses, Hering et al. (2009) indicated five parameters to describe species sensitivity to climate change impacts: endemism, preference for springs, preference for cold water temperatures, a short emergence period, and restricted ecological niches in terms of feeding types. Such parameters need to be considered under a global warming scenario.

This set of subjects constitutes a minimal knowledge that could be used by environmental managers engaged in biological monitoring of streams and to guide environmental authorities to strengthen the meteorological stations, foster databases and develop environmental models to forecast climatic changes.

\subsection{Riparian zones under a global change scenario}

Riparian zone is the transition between terrestrial and aquatic river environments (Gregory et al., 1992). This zone is influenced by climate, geomorphology, altitude, and local soil conditions (Verry et al., 2000; Naiman et al., 2005). Therefore, environmental conditions in riparian zones can be extremely heterogeneous, leading to high plant diversity (Silva et al., 2008).

The riparian zone has an important role in protection, filtration and erosion control of stream 
margins. Riparian plants supply streams with nutrients and buffer dial temperature and light fluctuations (Lima, 1989). The riparian zone also acts as a filter for runoff, and the accumulation of large plant debris enhances the accumulation of litter, which is processed in situ and provides energy to local food webs (Abelho, 2001).

Despite their importance, there are many open questions regarding the functioning of riparian zones and their biological importance for headwater streams. For instance, although riparian zones generally have a high diversity and density of trees, which supply streams with energy and nutrients (see the next section), on the other hand, there are systems where trees are sparse and there is a predominance of shrubs and grasses (e.g., Brazilian Cerrado). However, we still need to answer basic questions to understand functioning of riparian zone, as described to follow: How important is each species of the riparian vegetation to supplier of energy for aquatic trophic webs in these systems? Is the chemistry composition of riparian plants affected by soil and climate? Changes in dominant plants (and therefore detritus composition) affect nutrient cycling? Do litterfall and therefore nutrient input into streams and rivers follow a seasonal pattern?

Ongoing changes in nutrient load in headwaters (due to urbanizations and increased use of fertilizers), forest cover (due to the increase in tree crops agriculture and animal farming) and increases in temperature and stochastic changes in precipitation (due to global warming) are likely to affect riparian vegetation. Under these scenarios, how leaf traits of riparian plants are affected by climate change? Given that leaf litter from nutrient rich plants are likely to increase nutrients in water, do changes in dominant plants (and therefore leaf traits) affect nutrient cycling? Do changes in plant identity in the riparian zones affect seasonality of litter input?

Will a continuous increase in nutrients in the water (due do fertilization and urban pollution - global increase in nutrients in waters) affect the structure of tree riparian assemblages replacing species with low by species with high nutrient requirements? Under global climatic change, what will be more important for riparian tree assemblages, changes in temperature or changes in hydrology? Finally, with the ongoing colossal waterworks to transfer waters across distinct basins, how will changes from intermittent to permanent water flow affect riparian tree assemblages? Such information is urgently needed to implement scientifically sound management and conservation programs.

\subsection{The interchange of materials and biota between headwater streams and riparian zones}

Stream food webs are usually sustained by allochthonous and autochthonous energy sources. Headwater streams are generally shaded by vegetation which simultaneously limits in situ primary production and provides allochthonous organic material, such as leaves, flowers, seeds, insects and other organic material that support stream food webs (Paetzold et al., 2005). Tropical systems are notably diverse, and, for instance, the role of terrestrial insects supplying energy to the fish community level in low order streams and lakes has been poorly documented (but see Mehner et al., 2005; Barreto and Aranha, 2006). Likewise, since most stream invertebrates have terrestrial adult stages, little is known about their contribution to terrestrial food webs. Given the importance of vegetation as a food source for aquatic insects and the fact that terrestrial insects fall into stream waters, what happens when the tree riparian vegetation is removed or replaced? Vegetation removal and replacement are threats that have been exacerbated by the demand of wood for the paper mill industry, food production and biofuels. We expect that the removal of tree riparian vegetation will result in increased autochthonous energy incorporation into food webs and decreased importance of terrestrial detritus and insects.

However, quantitative data on energy movements across terrestrial-aquatic boundary are still missing. Additionally, the origin of material used by aquatic consumers (and therefore, energy) is poorly documented. On this subject, stables isotopes of carbon $\left(\delta^{13} \mathrm{C}\right)$ and nitrogen $\left(\delta^{15} \mathrm{~N}\right)$ can be an important tool (Martinelli et al., 2009). This method is based on the premise that the isotopic ratio varies in a predictable way and that the isotope ratio of the organisms' tissues reflects their diet (Ometto et al., 2005). The comparison between the isotopic signals from food sources and their bodies will help clarify the origin of their resources (Martinelli et al., 2009). The carbon isotope $\left(\delta^{13} \mathrm{C}\right)$ is used to determine carbon sources because it is stable across food webs, and nitrogen isotope $\left(\delta^{15} \mathrm{~N}\right)$ can be used as an indicator of trophic level because it tends to increase from one trophic level to the next (Martinelli et al., 2009).

In summary, there is a clear interdependence between streams and riparian forests in terms of 
energy flow because forests are a major provider of nutrients in the form of organic matter for aquatic benthic invertebrate consumers (Cummins et al., 1995). Therefore, changes in the structure of the riparian vegetation have the potential to directly affect energy sources and the input of nutrients, sediments and pollutants. We propose that studies investigating changes in riparian forests should address two questions. First, how these changes affect the energy interchange between terrestrial and aquatic environments and, second, how these changes affect the origin of the energy used by consumers. In a global changing world, how do changes in temperature, forest cover, hydrology and chemical pollution of stream water affect the interchange of materials (litter and invertebrates), and thus the energy flux, between riparian zones and streams?

\subsection{Land use affects aquatic biota and ecological processes}

Forests are among the most productive systems on Earth with up to $2.5 \mathrm{~kg}$ of dry mass produced per square meter every year (Ricklefs, 2005). Because only $-10 \%$ of the energy produced in one trophic level is available for the next, nearly $90 \%$ of the fixed energy in the forest will become part of the detrital loop and, inevitability, a portion of this energy will reach aquatic systems through streams (Ricklefs, 2005).

As soon as the leaves fall into the water, they start losing mass, producing fine particulate organic matter, dissolved organic matter and $\mathrm{CO}_{2}$. This decrease in mass is mirrored by an increase in microbial biomass and respiration. Moreover, if we place decomposing leaves in petri dishes with water, we obtain a large variety of spores from a group of fungi known as aquatic hyphomycetes. These fungi are the main responsible for microbial decomposition (Abelho et al., 2005).

If we protect leaves in the stream from invertebrates, their decomposition rates will be retarded (Gulis et al., 2006). This reduction is observed because a particular group of stream invertebrates actively feed on the decomposing leaves (Graça, 2001). Moreover, many stream invertebrates as chironomids are able to ingest leaves that are in good condition when no other food sources are available (e.g., Callisto et al., 2007).

Currently, there is a large body of literature showing that the rates at which litter is decomposed and energy is incorporated into streams are largely controlled by chemical quality of the litter. For instance, soft leaves rich in nutrients tend to decompose faster than tough, nutrient poor leaves and leaves protected against decomposers and invertebrate consumers (e.g., Gulis et al., 2006). If leaf litter is so important for the stream biota, how will global threats affect the decomposition processes in Brazilian streams? As stated above, one of the major factors leading to global changes is forest degradation and/or conversion, which includes planting tree monocultures. Worldwide, one of the most frequently planted trees, for instance, is eucalyptus. Graça et al. (2002) summarized biological changes in Iberian streams followed by the conversion of deciduous forests in eucalyptus monocultures. Oils and polyphenols extracted from eucalyptus leaves were shown to inhibit fungal growth and impair feeding by shredders under laboratory conditions (Canhoto and Graça, 1999). In the field, streams running though eucalyptus plantations showed a decreased fungal diversity (Bärlocher and Graça, 2002) and a decreased abundance of invertebrates (Abelho and Graça, 1996). These studies in the Iberian Peninsula tell us that forest changes are likely to affect the aquatic biota. In Brazil, the effects of eucalyptus plantations has been studied at small scale (e.g., Gonçalves et al., 2012), and future works should discuss the ecological effects of Brazilian forests conversion (not only eucalyptus but also soybeans, sugarcane, and others) on stream organisms and processes at a broader scale.

Besides global warming and nutrient enrichment, land use is responsible for drastic changes in natural vegetation cover which reduce or completely eliminate the riparian zones of headwaters and therefore promote changes in the whole freshwater system. For instance, the substitution of vegetation by farms, pasture and agricultural lands leads to changes in the functional feeding groups of invertebrates (Encalada et al., 2010).

Several of the ongoing global threats may interact. As forest changes may interact with the raising temperature (e.g., affecting both decomposition rates and decomposers distributions; Ferreira and Chauvet, 2011a) and atmospheric $\mathrm{CO}_{2}$ levels, it may result in changes in litter quality and may decrease litter consumption by invertebrates (see Ferreira et al., 2010). Further, simultaneous increases in temperature and nutrients may result in altered decomposition (Ferreira and Chauvet, $2011 \mathrm{~b}$ ). However, most of previous studies have been carried out in temperate systems with very different temperature regimes, hydrologic 
conditions and basal nutrient levels when compared to Brazil, and it is difficult to generalize these patterns for tropical freshwater systems.

The set of studies mentioned above raises questions regarding the functioning of headwater streams and management practices. For instance, knowing that riparian trees subsidize streams with leaves ranging in nutritional quality and the timing of litter inputs, how far could monoculture expand without compromising natural ecological processes and functioning in stream ecosystems? How environmental-friendly are biofuels resulting from forest replacement by sugar cane plantations that deeply modify the amount and quality of organic matter reaching streams? Finally, how can our knowledge of litter dynamics in streams (see Palmer and Febria, 2012; Woodward et al., 2012) be used for environmental management?

\subsection{The dynamics of allochthonous organic matter}

Riparian vegetation subsidizes streams with energy in the form of plant detritus (up to $90 \%$ of the energy used in the system, Abelho, 2001) and invertebrates (see section 4). Plant detritus includes leaf litter, wood and reproductive material. Leaves decompose quickly and are used as energy sources by detritivores and decomposers. Wood debris are more difficult to incorporate into secondary production, but they play an important ecosystem role by increasing the retention of organic matter and sediments (Grigg and Mulligan, 1999). Finally, reproductive material is quantitatively less important, more variable across systems and seasons and has been less studied. In this section, we will concentrate in the importance of leaf litter.

Quantitative studies aiming to assess the energy (litter) transference across the terrestrialaquatic boundaries in tropical low order streams, particularly across Brazilian biomes are scarce. We know now that, unlike the traditional belief, litterfall is seasonal in many tropical systems (e.g., Gonçalves et al., 2006; França et al., 2009) and is affected by hydrology and wind events. Rain patterns and windy events have the potential to affect productivity (by controlling the energy transference to water), retention (the lower the precipitation, higher the retention in a stream stretch) and disposal of different fractions of organic matter in streams (Tabacchi et al., 1998) and, presumably, the production of aquatic detritivores and their predators, such as fish, birds and riparian arthropods.
In general, it is assumed that vertical inputs, accounting for $80-90 \%$ of total contribution, are more important than lateral input $(<20 \%$, Pozo et al., 1997) and these values depend on the wind and rainfall patterns, the slope, and on the movement of animals. However, studies in Cerrado headwaters challenge these general observations as horizontal and vertical inputs seem to be similar (Gonçalves et al., 2006; França et al., 2009).

Would the contribution of vertical, lateral and upstream inputs change in a drier environment due to global warming? Moreover, how do those hypothetical changes affect the litter quality? As mentioned before, if global warming affects riparian vegetation, how would changes in riparian vegetation affect the dynamics of organic matter, the organic matter standing stock and nutrient input into streams? These questions should be addressed in future research.

\subsection{Small streams need unique monitoring policies}

Given the strong linkage with terrestrial environments, small streams are prone to many land perturbations. In a seminal paper on safe planetary boundaries, Rockström et al. (2009) identified the 10 worst threats to the planet and have shown that seven of them affect fresh waters (e.g., global water consume for agriculture, industry and/or personal use). Due to their unique biodiversity and their role as water supplier for human use, there is a need to understand the ecological functioning of rivers and the ecological effects of global changes and for developing practical conservation measures.

Biological responses caused by global changes need to be documented in detail. However, to perform this documentation, there is a need for adjusted, reproducible and sensitive sampling protocols. This subject has been tackled, for example, by a consortium involving the academy (Universidade Federal de Minas Gerais, Universidade Federal de Lavras, Pontifícia Universidade Católica de Minas Gerais and Centro Federal de Educação Tecnológica de Minas Gerais), the industry (Companhia Energética de Minas Gerais), and international partners by Oregon State University and the US Environmental Protection Agency, USA. The consortium has been adapting, adjusting and validating the IBI Protocols proposed by the US-EPA for the Cerrado, including wadeable streams and reservoirs in the Minas Gerais state.

Such labor includes standardizing sampling at large-scale and laboratory procedures in which landscape (land use types and human occupation) 
and physical and chemical metrics of sites have been used to interpret the environmental conditions faced by fishes and invertebrates (Ligeiro et al., 2013). Such initiatives will support political and environmental decision makers.

Once major monitoring processes are done, the next step will be to ensure that the governmental and environmental agencies will implement a strategy capable of identifying ongoing changes and establish mitigation measures.

\section{Questions Under Global Change}

In general, the knowledge regarding the effects of global changes in headwater streams is empirical, speculative and/or associative. In Brazil, we are poorly prepared to understand the effects of such changes. Within this context and in addition to the questions noted on the previous pages, we propose the following subjects to be addressed in future Brazilian studies on climate change:

a. Many ecological studies on global change have been addressed to model the potential distribution of species in future climate scenarios. However, most of these studies have dealt with terrestrial species, particularly plants. What would be the future distribution of aquatic species in stream ecosystems under a global warming scenario? Are they similar to those predicted for terrestrial organisms? Will the potential impacts on stream biota be dependent on streams differing in size, altitude and location (e.g., temperate $v$ s. tropical sites)?

b. Can we anticipate the main effects of global warming using manipulative experiments? If so, what are the effects of global warming on reproductive success, generation time and physiology of species?

c. What are the main consequences of climate change at species or population level: simple adaptation, demographic change, range reduction, range shift or extinction?

d. Two of the main environmental stressors related to climatic change are warming of waters and changes in hydrology (Durance and Ormerod, 2009). How the oscillations of climatic variables influence survival, growth, fecundity and production and therefore, population dynamics?

e. How gene flow among populations and their genetic structure will be affected by global changes? Consequently, how this will translate in changes of phenotypic, physiological and life-history traits of freshwater species? f. Do climate changes induce alterations in the thermal tolerance, bioenergetics, and dynamics of development and dispersion of species?

g. How do global changes affect the land-water interactions (e.g., energy flow) in headwater streams?

All these questions must be faced and represent a high challenge for the future Brazilian limnologists.

\section{Acknowledgements}

Authors wish to thank the invitation by the Organizing Committee of the Brazilian Limnology Congress to organize this section and to discussions and comments by our colleagues Leandro Oliveira, Luiz Hepp, and Maurício Petrucio. We also thank anonymous referees and support by the Editor in Chief Antonio Camargo, whose insightful comments improved the manuscript considerably. Financial support by FAPEMIG, FAPDF, CAPES, CNPq, Pró-Reitorias de Pós-Graduação e Pesquisa of our Universities were fundamental to cover travel and stay expenses during the Congress. DB was supported by Projeto PROEP supported by CNPq (number 400107/2011-2).

\section{References}

ABELHO, M. 2001. From litterfall to breakdown in streams: a review. The Scientific World, vol. 1, p. 656-680. PMid:12805769. http://dx.doi. org/10.1100/tsw.2001.103

ABELHO, M., CRESSA, C. and GRAÇA, MAS. 2005. Microbial biomass, respiration and decomposition of Hura crepitans L. (Euphorbiaceae) leaves in a tropical stream. Biotropica, vol. 37, p. 397-402. http://dx.doi. org/10.1111/j.1744-7429.2005.00052.x

ABELHO, MM. and GRAÇA, MAS. 1996. Effects of eucalyptus afforestation on leaf litter dynamics and macroinvertebrate community structure of streams in Central Portugal. Hydrobiologia, vol. 324, p.195-204. http://dx.doi.org/10.1007/BF00016391

BÄRLOCHER, F. and GRAÇA, MAS. 2002. Exotic riparian vegetation lowers fungal diversity but not leaf decomposition in Portuguese streams. Freshwater Biology, vol. 47, p. 1123-1135. http://dx.doi. org/10.1046/j.1365-2427.2002.00836.x

BARRETO, AP. and ARANHA, JMR. 2006. Alimentação de quatro espécies de Characiformes de um riacho de Floresta Atlântica, Guaraqueçaba, Paraná, Brasil. Revista Brasileira de Zoologia, vol. 23, p. 779-788. http://dx.doi.org/10.1590/S010181752006000300023

BENDA, L., HASSAN, MA., CHURCH, M. and MAY, CL. 2005. Geomorphology of steepland headwaters: the transition from hill slopes to channels. Journal 
of the American Water Resources Association, vol. 41, p. 835-851.

BROOKS, AJ., CHESSMAN, BC. and HAUEUSLER, T. 2011. Macroinvertebrate traits distinguish unregulated rivers subject to water abstraction. Journal of the North American Benthological Society, vol. 30, no. 2, p. 419-425. http://dx.doi.org/10.1899/10074.1

CALLISTO, M., GONÇALVES, JF. and GRAÇA, MAS. 2007. Leaf litter as a possible food source for chironomids (Diptera) in Brazilian and Portuguese headwater streams. Revista Brasileira de Zoologia, vol. 24, p. 442-448. http://dx.doi.org/10.1590/ S0101-81752007000200023

CANHOTO, CM. and GRAÇA, MAS. 1999. Leaf barriers to fungal colonization and shredders (Tipula lateralis) consumption of decomposing Eucalyptus globulus. Microbial Ecology, vol. 37, p. 163-172. PMid:10227874. http://dx.doi.org/10.1007/ s002489900140

COOPER, SD., DIEHL, S., KRATZ, K. and SARNELLE, O. 1998. Implications of scale for patterns and processes in stream ecology. Australian Journal of Ecology, vol. 23, p. 27-40. http://dx.doi. org/10.1111/j.1442-9993.1998.tb00703.x

COSTANZA, R., D’ARGE, R., GROOT, R., FARBER, S., GRASSO, M., HANNON, B., LIMBURG, K., NAEEM, S., O'NEILL, RV., PARUELO, J., RASKIN, RG., SUTTON, P. and VAN DEN BELT, M. 1997. The value of the world's ecosystem services and natural capital. Nature, vol. 387, p. 253-260. http://dx.doi.org/10.1038/387253a0

CUMMINS, KW., CUSHING, CE. and MINSHALL, GW. 1995. Introduction: an overview of stream ecosystems. In CUSHING, CE., CUMMINS, KW. and MINSHALL, GW., eds. River and Stream Ecosystems. New York: Elsevier. p. 1-8.

DINIZ-FILHO, JAF., BINI, LM., RANGEL, TF., LOYOLA, RD., HOF, C., NOGUÉS-BRAVO, D. and ARAÚJO, MB. 2009. Partitioning and mapping uncertainties in ensembles of forecasts of species turnover under climate change. Ecography, vol. 32, p. 897-906. http://dx.doi.org/10.1111/j.16000587.2009.06196.x

DUDGEON, D., ARTHINGTON, AH., GESSNER, MO., KAWABATA, ZI., KNOWLER, DJ., LEVEQUE, C., NAIMAN, RJ., PRIEURRICHARD, AH., SOTO, D., STISSNY, MLJ. and SULLIVAN, CA. 2006. Freshwater biodiversity: importance, threats, status and conservation challenges. Biological Reviews, vol. 81, p.163-182. PMid:16336747. http://dx.doi.org/10.1017/ S1464793105006950

DURANCE, I. and ORMEROD, SJ. 2009. Trends in water quality and discharge confound longterm warming effects on river macroinvertebrates.
Freshwater Biology, vol. 54, no. 2, p. 388-405. http:// dx.doi.org/10.1111/j.1365-2427.2008.02112.x

ENCALADA, A., CALLES, J., FERrEIRA, V., CANHOTO, C. and GRAÇA, MAS. 2010. Riparian land use and the relationship between the benthos and litter decomposition in tropical montane streams. Freshwater Biology, vol. 55, no. 8, p. 1719-1733.

FEIO, MJ. and POQUET, JM. 2011. Predictive models for freshwater biological assessment: statistical approaches, biological elements and the Iberian Peninsula experience: a review. International Review of Hydrobiology, vol. 96, p. 321-346. http://dx.doi. org/10.1002/iroh.201111376

FERREIRA, V. and CHAUVET, E. 2011a. Future increase in temperature more than decrease in litter quality can affect microbial litter decomposition in streams. Oecologia, vol. 167, p. 279-291. PMid:21461934. http://dx.doi.org/10.1007/s00442-011-1976-2

FERREIRA, V. and CHAUVET, E. 2011b. Synergistic effects of water temperature and dissolved nutrients on litter decomposition and associated fungi. Global Change Biology, vol. 17, p. 551-564. http://dx.doi. org/10.1111/j.1365-2486.2010.02185.x

FERREIRA V., GONÇALVES AL., GODBOLD DL. and CANHOTO C. 2010. Effect of increased atmospheric $\mathrm{CO}_{2}$ on the performance of an aquatic detritivore through changes in water temperature and litter quality. Global Change Biology, vol. 16, p. 3284-3296. http://dx.doi.org/10.1111/j.13652486.2009.02153.x

FRANÇA, JS., GREGÓRIO, RS., PAULA, JD., GONÇALVES, JFJr., FERREIRA, FA. and CALLISTO, M. 2009. Composition and dynamics of allochthonous organic matter inputs and benthic stock in a Brazilian stream. Marine and Freshwater Research, vol. 60, p. 990-998. http://dx.doi. org/10.1071/MF08247

FRISSELL, CA., WISS, WJ., WARREN, CE. and HUXLEY, MD. 1986. A hierarchical framework for stream classification: viewing streams in a watershed context. Environmental Management, vol. 10, p.199214. http://dx.doi.org/10.1007/BF01867358

GESSNER, MO., SWAN, CM., DANG, CK., MCKIE, BG., BARDGETT, RD., WALL, DH. and HATTENSCHWILER, S. 2010. Diversity meets decomposition. Trends in Ecology and Evolution, vol. 25, no. 6, p. 372-380. PMid:20189677. http:// dx.doi.org/10.1016/j.tree.2010.01.010

GONÇALVES, JFJr., FRANÇA, JS. and CALLISTO, M. 2006. Dynamics of allochthonous organic matter in a tropical Brazilian headstream. Brazilian Archives of Biology and Technology, vol. 49, p. 967-973. http:// dx.doi.org/10.1590/S1516-89132006000700014

GONÇALVES, JFJr., REZENDE, RS., MARTINS, NM. and GREGÓRIO, RS. 2012. Leaf breakdown in an Atlantic Rain Forest stream. Austral Ecology, 
vol. 37, p. 807-815. http://dx.doi.org/10.1111/ j.1442-9993.2011.02341.x

GRAÇA, MAS. 2001. The role of invertebrates on leaf litter decomposition in streams - a review. International Review of Hydrobiology, vol. 86, p. 383-393. http://dx.doi.org/10.1002/15222632(200107)86:4/5<383::AID-IROH383>3.0. CO;2-D

GRAÇA, MAS., POZO, J., CANHOTO, C. and ELOSEGI, A. 2002. Effects of Eucalyptus plantations on detritus, decomposers and detritivores in streams. The Scientific World Journal, vol. 2, p. 1173-1185. PMid:12805976. http://dx.doi.org/10.1100/ tsw.2002.193

GREGORY, SV., SWANSON, FJ., MCKKE, WA. and CUMMINS, KW. 1992. An ecosystem perspective of riparian zones. BioScience, vol. 41, p. 540-551.

GRIGG, AH. and MULLIGAN, DR. 1999. Litterfall from two eucalypt woodlands in central Queensland. Australian Journal of Ecology, vol. 24, p. 662-664. http://dx.doi.org/10.1046/j.14429993.1999.00991.x

GULIS, V., FERREIRA, V. and GRAÇA, MAS. 2006. Stimulation of leaf litter decomposition and associated fungi and invertebrates by moderate eutrophication: implications for stream assessment. Freshwater Biology, vol. 51, p. 1655-1669. http:// dx.doi.org/10.1111/j.1365-2427.2006.01615.x

HEINO, J., PARVIAINEN, J., PAAVOLA, R., JEHLE, M., LOUHI, P. and MUOTKA, T. 2005. Characterizing macroinvertebrate assemblage structure in relation to stream size and tributary position. Hydrobiologia, vol. 539, p. 121-130. http:// dx.doi.org/10.1007/s10750-004-3914-3

HERING, D., SCHMIDT-KLOIBER, A., MURPHY, J., SOFIE, L., ZAMORA-MUÇOZ, C., JESFFLS, ML., PEZ-RODR, G., HUBER, T. and WOLFRAM, G. 2009. Potential impact of climate change on aquatic insects: a sensitivity analysis for European caddisflies (Trichoptera) based on distribution patterns and ecological preferences. Aquatic Science, vol. 71, p. 3-14. http://dx.doi.org/10.1007/s00027009-9159-5

ISAAK, DJ., RIEMAN, B., LUCE, C., PETERSON, E., VERHOEF, JAY., DUNHAM, J., ROPER, B., ARCHER, E., HORAN, D., CHANDLER, G., NAGEL, D. and PARKES, S. 2011. Stream thermal regimes and aquatic ecosystems in a changing climate. Conservation Biology, vol. 22, no. 3, p. 521-533.

LIGEIRO, R., HUGHES, RM., KAUFMANN, PR., MACEDO, DR., FIRMIANO, KR., FERREIRA, W., OLIVEIRA, DR., MELO, AS. and CALLISTO, M. 2013. Defining quantitative stream disturbance gradients and the additive role of habitat to explain invertebrate richness. Ecological Indicators, vol. 25, p. 45-57. http://dx.doi.org/10.1016/j. ecolind.2012.09.004
LIMA, WP. 1989. Funçáo hidrológica da mata ciliar. In Anais do Simpósio sobre mata ciliar, 1989. São Paulo: Fundação Cargill. p. 25-42.

MARTINELLI, L., OMETTO, JP., FERRAZ, E., VICTORIA, R., CAMARGO, PB. and MOREIRA, M. 2009. A composição isotópica do carbono na hidrosfera: Desvendando questóes ambientais com isótopos estáveis. São Paulo: Oficina de Textos. cap. 8, p. 80-91.

MEHNER, T., IHLAU, J., DORNER, H. and HOLKER, F. 2005. Can feeding of fish on terrestrial insects subsidize the nutrient pool of lakes? Limnology and Oceanography, vol. 50, no. 6, p. 2022-2031. http://dx.doi.org/10.4319/lo.2005.50.6.2022

MÉIO, BB., FREITAS, CV., JATOBÁ, L., SILVA, MEF., RIBEIRO, JF. and HENRIQUES, RPB. 2003. Influência da flora das florestas Amazônica e Atlântica na vegetação do cerrado sensu stricto. Revista Brasileira de Botânica, vol. 26, p. 437-444.

MUNN, MD., WAITE, RI, LARSEN, DP. and HERLIHY, AT. 2009. The relative influence of geographic location and reach-scale habitat on benthic invertebrate assemblages in six ecoregions. Environmental Monitoring and Assessment, vol. 154, no. 1-4, p. 1-14. PMid:18629444. http://dx.doi. org/10.1007/s10661-008-0372-9

NAIMAN, RJ., DÉCAMPS, H. and McCLAIN, ME. 2005. Riparian Ecology, Conservation and Management of Streamside Communities. San Diego: Elsevier Academic Press.

OMETTO, JPHB., MARTINELLI, LA., CAMARGO, PB. and MOREIRA, MZ. 2005. Uso de isótopos estáveis em estudos ambientais. In: ROLAND, F., CÉSAR, D. and MARINHO, M. (Org.). Lições de Limnologia. São Carlos: RIMA. p. 461-485.

PAETZOLD, A., SCHUBERT, CJ. and TOCKNER, K. 2005. Aquatic terrestrial linkages along a braided-river: riparian arthropods feeding on aquatic insects. Ecosystems, vol. 8, p. 748-759. http://dx.doi. org/10.1007/s10021-005-0004-y

PALMER, MA. and FEBRIA, CM. 2012. The heartbeat of ecosystems. Science, vol. 336, p. 1393-1394. PMid:22700910. http://dx.doi.org/10.1126/ science. 1223250

POZO, J., GONZALEZ, E., DIEZ, JR., MOLINERO, J. and ELOSEGUI, A. 1997. Inputs of particulate organic matter to streams with different riparian vegetation. Journal of the North American Benthological Society, vol. 16, no. 3, p. 602-611. http://dx.doi. org/10.2307/1468147

PURVIS, A. and HECTOR, A. 2000. Getting the measure of biodiversity. Nature, vol. 405, p. 212-219. PMid:10821281. http://dx.doi. org/10.1038/35012221

REYNOLDSON, TB., NORRIS, RH., RESH, VH., DAY, KE. and ROSENBERG, DM. 1997. The 
reference condition: a comparison of multimetric and multivariate approaches to assess water-quality impairment using benthic macroinvertebrates. Journal of the North American Benthological Society, vol. 16, no. 4, p. 833-852. http://dx.doi. org/10.2307/1468175

RICKLEFS, RE. 2005. The Economy of nature. New York: Freeman.

ROCKSTRÖM, J., STEFFEN, W., NOONE, K., PERSSON, A., CHAPIN, F., LAMBIN, EF., LENTON, TM., SCHEFFER, M., FOLKE, C., SCHELLNHUBER, HJ., NYKVIST, B., DE WIT, CA., HUGHES, T., VAN DER LEEUW, S., RODHE, H., SORLIN, S., SNYDER, PK., COSTANZA, R., SVEDIN, U., FALKENMARK, M., KARLBERG, L., CORELL, RW., FABRY, VJ., HANSEN, J., WALKER, B., LIVERMAN, D., RICHARDSON, K., CRUTZEN, P. and FOLEY, JA. 2009. A safe operating space for humanity. Nature, vol. 461, p. 472-475. PMid:19779433. http://dx.doi.org/10.1038/461472a

SILVA, LCR., STERNBERG, LSL., HARIDASAN, M., HOFFMANN, WA., MIRALLES-WILHELM, F. and FRANCO, AC., 2008. Expansion of gallery forests into central Brazilian savannas. Global Change Biology, vol. 14, p. 2108-2118. http://dx.doi. org/10.1111/j.1365-2486.2008.01637.x

STATZNER, B., BONADA, N. and DOLÉDEC, S. 2007. Conservation of taxonomic and biological trait diversity of European stream macroinvertebrate communities: a case for a collective public database. Biodiversity and Conservation, vol. 16, no. 12, p. 3609-3632. http://dx.doi.org/10.1007/s10531007-9150-1

TABACCHI, E., CORREL, DL., HAUER, R., PINAY, G., PLANTY-TABACCHI, AM. and WISSMAR, RC. 1998. Development, maintenance and role of riparian vegetation in the river landscape.
Freshwater Biology, vol. 40, p. 497-516. http://dx.doi. org/10.1046/j.1365-2427.1998.00381.x

TISSEUIL, C., LEPRIEUR, F., GRENOUILLET, G., VRAC, M. and LEK, S. 2012. Projected impacts of climate change on spatio-temporal patterns of freshwater fish beta diversity: a deconstructing approach. Global Ecology and Biogeography, vol. 21, p. 1213-1222. http://dx.doi.org/10.1111/j.14668238.2012.00773.x

THUILLER, W., LAVOREL, S., ARAUJO, MB., SYKES, MT. and PRENTICE, IC. 2005. Climate change threats to plant diversity in Europe. Proceedings of the National Academy of Sciences, vol. 102, p. 82458250. PMid:15919825 PMCid:1140480.

VERRY, ES., HORNBECK, JW. and DOLLOF, CA., eds. 2000. Riparian Management in Forests of the Continental Eastern United States. Boca Ratón: Lewis Publishers.402 p.

VÖRÖSMARTY, CJ., McINTYRE, PB., GESSNER, MO., DUDGEON, D., PRUSEVICH, A., GREEN, P., GLIDDEN, S., BUNN, SE., SULLIVAN, CA., LIERMANN, CR. and DAVIES, PM. 2010. Global threats to human water security and river biodiversity. Nature, vol. 467, p. 555-561. PMid:20882010. http://dx.doi.org/10.1038/nature09440

WOODWARD, G., GESSNER, MO., GILLER, PS., GULIS, V., HLADYZ, S., LECERF, A., MALMQVIST, B., McKIE, BG., TIEGS, SD., CARISS, H., DOBSON, M., ELOSEGI, A., FERREIRA, A., GRAÇA, MAS., FLEITUCH, T., LACOURSIÈRE, JO., NISTORESCU, M., POZO, J., RISNOVEANU, G., SCHINDLER, M., VADINEANU, A., VOUGHT, LBM. and CHAUVET, E. 2012. Continental-scale effects of nutrient pollution on stream ecosystem functioning. Science, vol. 336, p. 1438-1440. PMid:22700929. http://dx.doi.org/10.1126/science. 1219534

Received: 28 June 2012 Accepted: 05 December 2012 